\title{
SISTEM EKONOMI ISLAM DENGAN ASPEK KEHIDUPAN MASYARAKAT MADANI DITINJAU DARI HUKUM ISLAM
}

\author{
Dwika Mayasari, Sarah Wijayanti Putri \\ Institut Agama Islam Negeri Kediri \\ Dwika.maya06@gmail.com \\ Sarah Wijayanti Putri \\ Institut Agama Islam Negeri Kediri \\ Sarahwijayanti56@gmail.com
}

\begin{abstract}
Abstrak
Ekonomi Islam merupakan sarana dalam mewujudkan ekonomi masyarakat madani. Kegagalan sistem konvensional membuat terjadi penyimpangan dari nilai sosial dan nilai normatif moral masyarakat sehingga sistem itu dianggap gagal dalam membentuk sarana ekonomi masyarakat. Untuk itu instrumen ekonomi syari'ah merupakan salah satu alternatif dalam pembentukan ekonomi masyarakat madani melalaui instrumen baitul maal, lembaga zakat, lembaga wakaf, sedekah, dan sebagainya.
\end{abstract}

Kata Kunci: Ekonomi Islam, Masyarakat Madani.

\section{Abstract:}

Economic of Islam is supporting facilities for in realizing public chartered investment counsel madani. Fails of conventional system makes happened variation from value social and normative value of public morale so that the system is assumed to fails in forming faciliti public chartered investment counsel. For the purpose intstrument chartered investment counsel syari'ah is one of alternative in forming of public chartered investment counsel madani with instrument treasure house, religious obligatory institute, communal ownership institute, alms and all that.

Keywords: Islamic Economic, Civil Society. 


\section{Pendahuluan}

Masyarakat madani sebagai terjemahan dari civil society diperkenalkan pertama kali oleh Anwar Ibrahim yang menjabat sebagai Menteri Keuangan dan Timbalan Perdana Menteri Malaysia, pada ceramah yang beliau sampaikan di Simposium Nasional dalam rangka Forum Ilmiah pada Festival Istiqlal. Dalam ceramah tersebut disebutkan bahwa yang dimaksud dengan masyarakat madani ialah sistem sosial yang subur yang diasaskan pada prinsip moral yang menjamin keseimbangan antara kebebasan perorangan dengan kestabilan masyarakat. Masyarakat mendorong daya usaha serta inisiatif individu baik dari segi pemikiran, seni, pelaksanaan pemerintahan mengikuti undang-undang dan bukan nafsu atau keinginan invidu menjadikan keterdugaan atau predictability serta ketulusan atau transperensi sistem. ${ }^{1}$ Istilah itu diterjemahkan dari bahasa Arab "Mujtama' Madani” yang diperkenalkan oleh Prof. Naquib Attas. Kata Madani berarti civil atau civilized (beradab). Madani berarti juga peradaban.

Nurcholis Madjid mencoba melihat civil society berkaitan dengan masyarakat kota Madinah pada zaman Rasulullah SAW. Menurutnya, Piagam Madinah merupakan dokumen politik pertama dalam sejarah umat manusia yang meletakkan dasar-dasar pluralisme dan toleransi, sementara di Eropa baru dimulai dengan The Tolerasion Act of 1689.

Kutipan diatas memberi kesan bahwa masyarakat madani itu adalah suatu masyarakat yang terbebas dari penindasan penguasa, baik penguasa (pemerintah) maupun masyarakat sadar hukum yang berarti taat pada hukum, serta rukun damai antar sesama walaupun diantara mereka berbeda keyakinan (agama) rasa dan sebagainya. ${ }^{2}$

Munculnya konsep masyarakat masyarakat madani menunjukkan intelektual muslim Melayu mampu menginterprestasikan ajaran islam dalam kehidupan modern. Konsep masyarakat madani memiliki rentang waktu pembentukan yang sangat panjang sebagai hasil dari akumulasi pemikiran yang akhirnya membentuk profile konsep normatif seperti yang dikenal sekarang ini. Bahkan konsep ini pun masih akan berkembang terus sebagai akibat dari proses pengaktualisasian yang dinamis dari konsep tersebut dilapangan.

Dasar tatanan masyarakat madani memperoleh legitimasi kuat pada landasan tekstual al-Quran maupun hadis dan praktik generasi awal Islam. Landasan ini tercermin dalam

${ }^{1}$ Imam Sukardi, "Islam dan Civil Society," Jurnal Tsaqafah 6, No 1 (2010), 117.

2 Abu Tholib Khalik, “Masyarakat Madani dan Sosialisme," Jurnal Tapis 8, No. 2 (2012): 38. 
sikap budaya dan agama (cultural and religious attitude) seperti toleransi dan pluralis, serta pengakuan atas hak-hak asasi manusia. ${ }^{3}$

Islam merupakan sebuah agama memberikan konsep yang komprehensif dan integral, tidak hanya pada persoalan ubudiyah (ibadah) seperti shalat, puasa, zakat, dan amalan ibadah yang lainnya, tetapi juga menyangkut kode etik sosial yang digunakan manusia sebagai perangkat penataan sosial yang diarahkan pada kemaslahatan manusia itu sendiri. Al-Quran dan Hadis adalah representasi dari ajaran Islam yang komprehensif tersebut, yang di dalamnya memuat ajaran yang lengkap dalam berbagai aspek tak terkecuali masalah keilmuan atau pendidikan, bahkan Rasulullah menerima wahyu pertama berkenaan dengan pendidikan. ${ }^{4}$

Salah satu wacana yang menjadi dominan dalam perkembangan kelompok ilmu sosial adalah pembahasan tentang civil society, untuk pengertian civil society dalam berbagai istilah antara lain masyarakat madani, masyarakat warga, masyarakat kewargaan, masyarakat sipil, dan masyarakat beradab atau berbudaya. Sedangkan kata madani sendiri berasal dari bahasa arab yang artinya beradab. Masyarakat madani merupakan sistem ekonomi sosial yang subur berdasarkan prinsip moral yang menjamin keseimbangan antara kebebasan individu dengan kestabilan masyarakat.

Dalam khasanah pengkajian civil society Indonesia, tema ini bisa jadi sesuatu yang asing dan perlu sosialisasi intensif. Nilai-nilai transendentalis, yang dalam kasus Eropa Timur berasal dari pemikiran Yunani Kuno, bisa digali dari ajaran Islam seperti yang dikemukakan didepan berdimensi transenden dan horizontal. Terlebih di Indonesia dan umumnya di dunia Islam belum muncul epistimologi tandingan atas proyek pencerahan yang mampu memunculkan civil society. ${ }^{5}$

Masalah ekonomi merupakan masalah yang universal, karenanya seluruh dunia menaruh perhatian yang besar terhadap permasalahan ekonomi. Segala kegiatan yang bersangkutan untuk memenuhi keperluan ini dinamakan ekonomi. Islam memandang masalah ekonomi tidak dari sudut pandang kapitalis, sosialis dan juga tidak merupakan gabungan dari keduanya.

3 Achmad Jainuri, “Agama dan Masyarakat Madani: Rujukan Khusus tentang Sikap Budaya, Agama, dan Politik.” Jurnal al-Afkar. Edisi III, Tahun II (2000), 22.

4 Eko Nursalim, "Pendidikan Islam Menuju Masyarakat Madani di Era Globalisasi: Suatu Ikhtiar Menghadapi Tantangan Masyarakat Ekonomi Asean (MEA)," At-Turats: Jurnal Pemikiran Pendidikan Islam 10 No. 1 (2016): 43.

5 Wawan Mas'udi, "Masyarakat Madani: Visi Etis Islam tentang Civil Society," Jurnal Ilmu Sosial dan Politik 3, No. 2 (1999): 166. 
Islam memberikan perlindungan hak-hak kepemilikan individu, sedangkan untuk kepentingan masyarakat didukung dan diperkuat dengan tetap menjaga keseimbangan kepentingan publik dan invidu serta menjaga moralitas. ${ }^{6}$

Memasuki era global dengan kemajuan teknologi informatika di satu sisi dan kebangkitan nasionalisme dan spiritual di sisi lain. Budaya global juga ditandai dengan era "Ekonomi Baru" (Konsep Ekonomi Syariah) dan posisi hukum semakin diperlukan. Ilmu Ekonomi Syariah ialah ilmu tentang manusia yang meyakini nilai-nilai hidup islam. Ilmu Ekonomi syariah yang tidak hanya mempelajari individu sosial melainkan juga manusia dengan fitrah religousnya. Ilmu Ekonomi Syariah dikendalikan oleh nilai-nilai dasar Islam dalam operasionalnya yang berdasarkan perintah Al-Quran dan Sunnah.

Masuknya unsur Islam (ekonomi syariah) dalam cita hukum ekonomi Indonesia, bukan berarti mengarahkan ekonomi nasional ke arah ideologi ekonomi agama tertentu, tetapi dikarenakan ekonomi syariah sudah lama hidup dan berkembang tidak hanya di Indonesia, tetapi juga di dunia. Sistem ekonomi syariah adalah salah satu dari sistem-sistem ekonomi lainnya seperti kapitalisme dan sosialisme. Ekonomi Syariah keberadaannya mempunyai landasan yang kuat baik secara formal syar'i maupun formal konstitusi. ${ }^{7}$

Untuk menjelaskan secara benar terminologi masyarakat madani, ada dua level penting yang harus dipahami. Pertama, level prinsip-prinsip pengaturan kemasyarakatan dalam Islam, dalam ini penafsiran terhadap al-Quran dan hadis yang revelan harus dilakukan. Kedua, level historis, yaitu sejarah perkembangan masyarakat Arab yang dimulai dari pra-Islam sampai dengan periode masyarakat Madinah.

\section{Metode Penelitian}

Penelitian ini merupakan penelitian jenis kepustakaan (library research). Penelitian kepustakaan adalah penelitian yang dilakukan dengan cara mengumpulkan data, informasi, dan berbagai macam data-data lainnya yang terdapat dalam kepustakaan. Mengenai sumber data, karena ini sifatnya adalah kajian pustaka, maka obyek yang dapat dijadikan sumber dibagi menjadi dua, yaitu primer dan sekunder. Data primer adalah buku, jurnal, buletin dan

6 http://ediefendi23.blogspot.com/2016/01/ekonomi-islam-perkembangan-ekonomi.html (diakses 26 Oktober 2018).

${ }^{7}$ Eka Sakti Habibullah, "Hukum Ekonomi Syariah dalam Tatanan Hukum Nasional.” Al-Mashlahah: Jurnal Hukum Islam dan Pranata Sosial Islam 5, No. 9 (2017): 692-693. 
karya ilmiah yang berkaitan dengan masyarakat madani dan sekunder adalah buku-buku masih dianggap relevan dengan kajian penelitian. ${ }^{8}$

Penelitian kepustakaan juga dapat mempelajari beberapa hasil penelitian sebelumnya yang sejenis guna untuk mendapatkan landasan teori mengenai masalah yang akan diteliti. Sedangkan menurut para ahli kepustakaan merupakan kajian teoritis, referensi serta literatur ilmiah lainnya yang berkaitan dengan budaya, nilai dan norma yang berkembang pada situasi sosial yang diteliti. ${ }^{9}$

Penelitian kepustakaan menempati posisi yang penting dalam penelitian. Walaupun sebagian orang membedakan antara riset kepustakaan dan riset lapangan, namun keduanya memerlukan penelusuran pustaka. Ada perbedaan yang melekat pada riset kepustakaan dengan riset lapangan, perbedaan yang utama adalah pada tujuan, fungsi, atau kedudukan studi pustaka dalam masing-masing penelitian tersebut.

Riset lapangan, penelusuran pustaka sebagai langkah awal dalam rangka untuk menyiapkan kerangka penelitian yang bertujuan memperoleh informasi penelitian sejenis, memperdalam kajian teoritis. Sedangkan riset pustaka, penelurusan pustaka lebih daripada sekedar melayani fungsi-fungsi yang disebutkan untuk memperoleh data penelitiannya. Tegasnya riset pustaka membatasi kegiatannya hanya pada bahan-bahan koleksi perpustakaan saja tanpa terjun riset lapangan. ${ }^{10}$

Pendekatan yang digunakan dalam penelitian ini adalah pendekatan filosofis. Pendekatan filosofis digunakan untuk merumuskan secara jelas hakekat yang mendasari konsep-konsep pemikiran. Teknik pengumpulan datanya menggunakan teknik dokumentasi. Teknik dokumentasi adalah metode pengumpulan data yang dilakukan dengan cara mencari data tentang variabel penelitian dari beberapa macam dokumentasi seperti catatan, transkip, buku, surat kabar, majalah, dan jurnal. ${ }^{11}$

\section{Pengertian Ekonomi Islam}

Secara epistemologi, ekonomi berasal dari bahasa Yunani "oikonomia" yang terdiri dari dua kata yaitu oikos yang berarti rumah tangga dan nomos yang berarti aturan. Jadi ilmu

\footnotetext{
8 Irfan Charis," Pendidikan Islam dalam Masyarakat Madani Indonesia," Mudarrisa: Jurnal Kajian Pendidikan Islam 7, No. 2 (2015): 234.

9 Abdi Mirzaqon T, "Studi Kepustakaan Mengenai Landasan Teori Praktik Konseling Expressive Writing," Jurnal BK Unesa 8, No. 1 (2017), 4.

${ }^{10}$ Khatibah, "Penelitian Kepustakaan," Jurnal Iqra' 6, No. 1, (2011): 38.

${ }^{11}$ Irfan Charis, "Pendidikan Islam dalam Masyarakat Madani Indonesia," 235.
} 
ekonomi adalah ilmu yang mengatur rumah tangga, yang dalam bahasa inggris disebut "economies."

Menurut M. Akram Khan yang di maksud dengan ekonomi syariah adalah Ilmu Ekonomi Islam bertujuan untuk melakukan kajian tentang kebahagiaan hidup manusia (human falah) yang dicapai agar mengorganisasikan sumber daya alam atas dasar gotong royong dan partisipan. ${ }^{13}$

Dari definisi tersebut dapat disimpulkan bahwa ilmu ekonomi syariah adalah ilmu yang mempelajari aktivitas atau perilaku manusia secara aktual dan empirikal, baik dalam produksi, distribusi, maupun konsumsi berdasarkan syariat islam yang bersumber AlQur'an dan As-Sunnah serta ijma' para ulama. Ekonomi syariah bukan sekedar etika dan nilai yang bersifat normatif, tetapi juga bersifat positif sebab ia mengakaji aktivitas aktual manusia, problem-problem ekonomi masyarakat dalam prespektif islam. ${ }^{14}$

\section{Sumber Hukum Ekonomi Islam}

\section{Kitab Suci Al-Qur'an}

Al-Qur'an merupakan amanat sesungguhnya yang disampaikan Allah melalui ucapan Nabi Muhammad Saw. untuk membimbing umat manusia. Amanat ini bersifat universal, abadi dan fundamenta ${ }^{15}$

Sebuah pandangan dasar tentang karakteristik masyarakat madani yang ideal. Yang dikemukakan dalam QS. at-Taubah ayat 71 yang menjelaskan tentang sifat-sifat yang seharusnya disandang oleh orang-orang mukmin dalam kapasitas mereka sebagai sebuah masyarakat. Dari 6 siafat yang disebutkan dalam ayat tersebut, sifat yang pertama menggunakan ungkapan khabari berupa jumlah ismiyah yang mempunyai makna tetap. Lima sifat berikutnya menggunaan ungapan khabari juga tetapi dalam bentuk jumlah fi'liyah (kata kerja) yaitu : memerintah, melarang, menegakkan, menunaikan, dan taat. Penggunaan lima kata kerja ini mempunyai arti kata smua pekerjaan itu terus dilaksanakan dari waktu ke waktu sepanjang hayat manusia, sebagai proses yang tiada henti. ${ }^{16}$

12 Thohir Abdul Muhsin Sulaiman, Menanggulangi Krisis Secara Islam (Bandung: al-Ma'rif, 1982), 29.

13 Akram Khan, Economic Message of the Qur'an (Kuwait Islamic Book Publisher, 1996), 43.

14 Abdul Manan, Hukum Ekonomi Islam (Jakarta: PT Fajar Interpratama Mandiri, 2012), 29-30.

15 Muhammad Abdul Mannan, Teori dan Praktik Ekonomi Islam (Yogyakarta: PT. Dana Bhakti Wakaf, 1993), 29-32.

${ }^{16}$ Http://www.majalahgontor.net (Diakses pada 26 Oktober 2020). 


\section{Hadis dan Sunnah}

Penafsiran hadis dan sunnah harus memperhatikan perspektif sejarah dan arti penting fungsionalnya yang tepat dalam konteks sejarah karena dalam suatu masyarakat yang meluas secara cepat, penafsiran Al-Qur'an dan Sunnah haru menjadi tuntunan bagi pemahaman dan penerapan moral yang cerdas. ${ }^{17}$

\section{Ijma'}

Ijma' adalah suatu prinsip isi hukum baru yang timbul sebagai akibat dalam melakukan penalaran dan logikanya menghadapi suatu masyarakat yang meluas dengan cepat. Ijma' bersifat mempersatukan, namun sebenarnya tetap masih ada sisa perbedaan pendapat tertentu tentang suatu persoalan kecil yang tidak disepakati, tetapi hal ini oleh para ahli hukum agama di tafsirkan sebagai suatu pertanda adanya rahmat Tuhan terhadap umat-Nya. ${ }^{18}$

\section{Ijtihad}

Ijtihad berarti meneruskan setiap usaha untuk menentukan sedikit banyaknya kemungkinan suatu persoalan Syariat. Pengaruh hukumnya ialah bahwa pendapat yang diberikannya mungkin benar, walaupun mungkin salah. ${ }^{19}$

\section{Pandangan Islam tentang Ekonomi}

Khurshid Ahmad pernah melontarkan pertanyaan apakah masyarakat muslim bisa membangun perekonomian dengan mengikuti sistem kapitalis, sosialis maupun derivasinya, dengan ketergantungan (depedency) yang begitu kuat? Atau haruskah dilakukan rekonstruksi social ekonomi secara total dengan asumsi, gagasan dan pola yang unik dan bernilai khusus untuk pembangunan dalam masyarakat muslim?

Sebagai pemikir ekonomi muslim, Khursid Ahmad tentu berangkat dari realitas yang terjadi di negeri-negeri muslim. Di mana hampir sebagian besarnya memiliki sumber daya yang luar biasa tetapi keadaan ekonominya tetap tak berkembang, standar hidup rakyatnya masih rendah, dan bahkan cenderung hidup dalam keadaan subsisten. Mengalami ketimpangan dalam distribusi kekayaan, ketidakseimbangan dalam wilayah geografis, kesenjangan antara sektor ekonomi dan sosial, juga terjadi ketimpangan antara pusat

\footnotetext{
${ }_{17}$ Mannan, “Teori dan Praktik Ekonomi Islam,” 32-33.

18 Mannan, 34.

${ }^{19}$ Mannan, 35-37.
} 
industri dan daerah pertanian. Selain itu, juga mengalami ketergantungan yang luar biasa sebagai pengaruh berkepanjangan dari warisan hubungan ekonomi kolonial sebagai hubungan pusat pinggiran (centre-periphery relationship).

Dunia Islam mengalami paradoks, ketika mengunakan prototipe pertumbuhan sebagai pola pembangunan yang dirancang pakar dan praktisi barat yang kemudian “dijual" kepada perencana negara muslim melalui diplomasi internasional, tekanan ekonomi, infiltrasi intelektual dan cara lainnya.

Banyak kajian evaluasi kebijakan pembangunan dan kinerja ekonomi negara-negara muslim menunjukkan bahwa strategi imitasi gagal untuk menghasilkan kesejahteraan. Semua bukti menunjukkan bahwa usaha pembangunan selama ini masih lepas dari nafas Islami. Untuk mengurai persoalan pelik yang dihadapi negeri-negeri muslim tersebut harus dimulai dengan peletakan kerangka befikir.

Kerangka berfikir menjadi basis untuk menjawab persoalan-persoalan di atas. Dalam kerangka berfikir tersebut harus dicanangkan sebuah premis baru bahwa pembangunan ekonomi dalam kerangka ajaran Islam dan ilmu ekonomi pembangunan Islami berakar pada kerangka nilai yang ada dalam al-Qur'an dan as-Sunah. Al-Qur'an dan As-Sunah merupakan titik rujukan kita yang paling mendasar. Premis kedua dalam pendekatan ini menolak sikap imitatif. Model kapitalis maupun sosialis serta derivasinya bukan merupakan ideal type, kendatipun juga dapat mengumpulkan sumber-sumber yang bermanfaat untuk diadaptasikan atau diintegrasikan dalam kerangka Islam tanpa harus mengurangi nilai-nilai normatif yang ada.

Teori pembangunan seperti yang dikembangkan di Barat (negara-negara kapitalis, sosialis dan penganut derivasinya) banyak dipengaruhi oleh karakteristik unik, masalah spesifik, nilai eksplisit dan implisit serta infrastruktur sosial-politik-ekonomi yang khas dari khazanah peradabannya. Sehingga akan terjadi kesulitan besar dan bahkan cenderung kontraproduktif ketika dipaksakan untuk diadopsi secara penuh kedalam masyarakat muslim, hal ini disebabkan adanya perbedaan mendasar yang membentuk bangunan kemasyarakatan dari masing-masing peradaban.

Pendekatan Islam harus jelas bersifat ideologis dan berorientasi pada nilai-nilai yang terkandung di dalam Islam itu sendiri. Konsep pembangunan senantiasa terikat oleh kondisi budaya, sosial dan politik setempat. Pembangunan dalam Islam mempunyai pengertian khusus dan unik. Beberapa aspek pembangunan seperti keadilan sosial dan hak 
Dwika Mayasari, Sarah Wijayanti Putri, Sistem Ekonomi Islam dengan Aspek Kehidupan....

asasi (social justice and buman rights), mempunyai persamaan dengan konsep barat, meskipun banyak perbedaan dan memiliki dasar pokoknya yang berbeda.

Berdasarkan kronologis perbincangan di atas menjadi sangat relevan untuk mengkaji pandangan Islam dalam memecahkan persoalan ekonomi. Hal ini bermuara pada pengkajian konsep-konsep dasar Ilmu Ekonomi Islam untuk melakukan transformasi ekonomi masyarakat, khususnya masyarakat muslim. Harus diakui bahwa proyek ilmu ekonomi Islam dan Islamisasi ilmu ekonomi telah menjadi obor terdepan bagi proyek Islamisasi ilmu. Bahkan para praktisi perbankan dan keuangan Islam juga telah berhasil mengukuhkan terwujudnya sistem keuangan Islam secara global dan diakui eksistensinya dalam percaturan ekonomi pada masa sekarang.

Keberadaan sistem ekonomi Islam merupakan konsekuensi dari pandangan hidup Islam (Islamic worldview). Worldview Islam yang menjadi dasar ini oleh para Ulama dan Cendekiawan muslim disebut dengan berbagai pendekatan istilah seperti : Maulana alMaududi mengistilahkannya dengan Islami nazariat (Islamic Vision), Sayyid Qutb menggunakan istilah al-Tasawnur al-Islami (Islamic Vision), Mohammad Atif al-Zayn menyebutnya al-Mabda' al-Islami (Islamic Principle), sedangkan Prof. Syed Naquib al-Attas menamakannya Ru'yatul Islam lil Wujud (Islamic Worldview).8

Meskipun secara istilah terjadi perbedaan penyebutan tetapi secara esensi terdapat kesamaan keyakinan para Ulama dan Cendekiawan tersebut bahwa pandangan hidup (worldview) seorang muslim haruslah menjadikan Islam sebagai sistem hidup yang mengatur semua sisi kehidupan manusia, yang menjanjikan kesejahteraan dan keselamatan dunia dan akhirat. Worldview ini lahir dari adanya konsep-konsep Islam yang mengkristal menjadi kerangka berpikir (mental framework).

Islam merupakan pedoman bagi manusia untuk hidup dan kehidupannya, baik itu dalam aktivitas ekonomi, politik, hukum maupun sosial budaya. Islam memiliki kaidahkaidah, prinsip-prinsip atau bahkan beberapa aturan spesifik untuk mengatur hidup dan kehidupan manusia. Islam mengatur hidup manusia dengan fitrahannya sebagai individu (hamba Allah Swt.) dan menjaga keharmonian dalam kehidupan sosial-kemasyarakatan. Dalam aktifitas kehidupan manusia, beberapa aspek aktifitas tersebut memiliki sistemnya tersendiri, misalnya aspek ekonomi, hukum, politik dan sosial budaya. Islam yang diyakini sebagai sistem yang terpadu dan menyeluruh tentu memiliki formulasinya sendiri dalam aspek-aspek tersebut. Sistem ekonomi Islam, sistem hukum Islam, sistem politik Islam dan 
sistem sosial-budaya Islam merupakan bentuk sistem yang spesifik dari konsep Islam sebagai sistem kehidupan.

Worldview Islam memberikan pijakan bahwa umat manusia adalah ciptaan Tuhan Yang Maha Kuasa, dan seluruh sumber kehidupan (resources) yang tersedia adalah amanahNya, maka secara otomatis umat manusia memiliki hubungan persaudaraan yang alamiah dan mereka juga harus bertanggungjawab kepada-Nya. Oleh karena itu, manusia tidak secara mutlak bebas untuk melakukan apa saja, akan tetapi mereka diharapkan untuk menggunakan sumber daya yang terbatas (limited resources) dan berinteraksi antara satu dengan lainnya, serta membangun lingkungan hidup sedemikian rupa sehingga mendukung usaha perwujudan kesejahteraan bersama (mutual welfare) setiap individu, tanpa melihat apakah mereka kaya atau miskin, hitam atau putih, lelaki atau perempuan serta anak-anak atau orang dewasa. Manusia juga diharapkan untuk tidak saja menjamin pencapaian tujuan materi, tetapi juga tujuan spiritual dan kemanusiaan, khususnya tentang keharmonisan sosial dan penghapusan anomie.

Islam menekankan pembanguan insan seutuhnya (buman development) menuju puncak kehidupan yang seindah-indahnya ( $f$ a absani taqwiin). Pembangunan mendasarkan diri pada konsep taækiyah an-nafs dengan titik tumpu pada penyempurnaan akhlak dan kepribadian. Karena pribadi adalah bagian penting dalam pembentukan peradaban. Asas ketenangan (internal harmony) merupakan hasil dari proses tąkiyah. Ibnu Khaldun pernah melukiskan betapa agama dapat menghasilkan transformasi sosial (social transformation). Sebaliknya ketika sebuah komunitas masyarakat terjebak pada kesenangan dan kemewahan maka akan lahir babak kehancuran dari peradaban (the decay of civilization). Konsep tarkiah ini maka diharapkan terbentuk konsep pembangunan Islami yang memiliki sifat komprehensif dan mengandung unsur spiritual, moral dan material, fokus usaha dengan jantung pembangunan itu sendiri adalah manusia.

Pembangunan ekonomi adalah aktifitas yang multidimensional pembangunan ekonomi menimbulkan sejumlah perubahan secara kuantitatif maupun kualitatif dan adanya prinsip sosial Islam yang dinamis untuk pemanfaatan sumber daya alam dan pemanfaatan ini dilaksanakan dengan semangat keadilan.

Kebijakan pembangunan Islami yang ideal harus berorientasi untuk: meningkatkan tingkat spiritual masyarakat Islam dan meminimalisasi kerusakan moral dan korupsi, memenuhi kewajibannya untuk kesejahteraan ekonomi dalam batas-batas sumber daya yang tersedia, dan menjamin keadilan distributif dan memberantas praktik eksploitasi. Islam 
mengajarkan falsafah kesejahteraan yang unik, komprehensif dan konsisten dengan fitrah manusia. Sebuah doktirn yang melekat dan menyatu dalam kepribadian masyarakat (built-in in-doctrination). Kesejahteraan individu dalam masyarakat Islam dapat terealisasi bila ada iklim yang cocok bagi: pelaksanaan nilai-nilai spiritual Islam secara keseluruhan untuk individu maupun masyarakat; pemenuhan kebutuhan pokok material manusia dengan cukup dan menitikberatkan pada nilai-nilai moral.

Untuk menjaga nilai spiritualitas, maka sebuah negara Islami harus menuju pada tiga arah; pertama, menciptakan suasana yang kondusif bagi tegaknya rumah tangga yang memungkinkan berlangsungnya pendidikan bagi generasi baru. Kedua, berusaha menciptakan sistem pendidikan yang dijiwai semangat Islam, ketiga menegakkan nilai dan norma Islam berupa penegakan hukum (legal enforcement). Juga terpenuhinya kebutuhankebutuhan pokok manusia seperti pelatihan dan pendidikan, tersedianya lapangan kerja (pekerjaan, profesi, bidang perdagangan), pakaian yang cukup, perumahan yang nyaman, lingkungan yang sehat dengan fasilitas kesehatan yang layak, dan fasilitas transportasi. Ketika kekuatan-kekuatan pasar tidak menguntungkan maka negara bisa berperan dengan kebijakan yang terbaik. Peranan negara ini tidak bisa disamaakan dengan istilah "intervensi" negara dibawah sistem kapitalis.

Kehidupan masyarakat yang diharapkan adalah proses secara bertahap untuk mencapai kejayaan suatu masyarakat. Masa kejayaan senantiasa membawa kemajuan dan kemakmuran, begitupula masa kemunduran peradaban Islam juga ditandai oleh kedzaliman, kemiskinan, dan kelaparan. ${ }^{20}$

\section{Konsep Masyarakat Madani}

Masyarakat madani dapat diartikan sebagai suatu masyarakat yang beradab dalam membangun, menjalani dan memaknai kehidupannya. Konsep masyarakat madani merupakan penerjamahan atau pengislaman konsep "civil society". Pemaknaan civil society sebagai masyarakat madani ini merujuk pada konsep dan bentuk masyarakat Madinah yang dibangun Nabi Muhammad. Masyarakat Madinah dianggap sebagai legitimasi historis pembentukan civil society dalam masyarakat muslim modern. ${ }^{21}$

${ }^{20}$ Nurnasrina, "Ekonomi Islam Sarana dalam Mewujudkan Ekonomi Masyarakat Madani," Hukum Islam 13, No. 1 (2013): 222-227.

${ }^{21}$ Ngudi Astuti, "Peran Umat Islam dalam Mewujudkan Masyarakat Madani di Indonesia," Jurnal Ilmiah Mimbar Demokrasi 11, No. 2 (2012): 87-88. 


\section{Sejarah Perkembangan Masyarakat Madani dalam Peradaban Islam}

Ada dua masyarakat madani dalam sejarah yang terdokumentasi sebagai masyarakat madani, yaitu:

1. Masyarakat Saba', yaitu masyarakat pada masa Nabi Sulaiman. Allah menggambarkan masyarakat madani dengan firman-Nya dalam QS. Saba' ayat 15.

2. Masyarakat Madinah setelah terjadi trakta, perjanjian Madinah antara Rasulullah Saw. beserta umat islam dengan penduduk Madinah yang beragama Yahudi dan beragama Watsani dari kaum Aus dan Khazraj. Perjanjian Madinah berisi kesepakatan ketiga unsur masyarakat untuk saling tolong menolong, menciptakan kedamaian dalam kehidupan sosial, menjadikan al-Quran sebagai konstitusi, menjadikan Rasulullah sebagai pemimpin dengan penuh ketaatan terhadap keputusan-keputusannya bagi penduduk untuk memeluk agama serta beribadah sesuai dengan ajaran agama yang dianutnya.

Secara historis kita lebih banyak mudah secara langsung merajuk pada “masyarakat"nya Ibnu Khaldun. Deskripsi masyarakatnya justru banyak mengandung muatan-muatan moral spiritual dan menggunakan agama sebagai landasan analisisnya. Masyarakat Madani merujuk kepada masyarakat dan negara yang diatur oleh hukum agama. Istilah Madani, Madinah (kota) dan din (agama) semuanya didasarkan dari akar kata din. Masyarakat Madani bermula dari perjuangan Nabi Muhammad menghadapi kondisi Jahiliah masyarakat Arab Quraisy di Mekkah. Beliau memperjuangkan kedaulatan, agar umatnya leluasa menjalankan syariat agama di bawah suatu perlindungan hukum dan mewujudkan cita-cita membentuk madaniyyah (beradab). ${ }^{22}$

\section{Karakteristik Masyarakat Madani}

Untuk merealisasikan masyarakat madani dibutuhkan prasyarat yang menjadi nilai universal (dapat diterima semua bangsa dan kelompok masyarakat) untuk tegaknya masyarakat yang beradab serta mencirikan peradaban manusia. Pra-syarat tersebut tidak dapat dipisahkan satu sama lain dan harus menjadi satu ke-satuan yang utuh. Karakteristik tersebut adalah adanya free public sphere, demokratis, toleransi, pluralisme dan keadilan sosial dan berkeadaban ${ }^{23}$

22 Astuti, 88-89.

23 http://www.academia.edu/1511157Gagasan Civil Society Hegelian dan Korporatisme Negara (Diakses 26 Oktober 2018). 
Free public sphere memiliki arti adanya ruang publik yang bebas dalam mengemukakan pendapat. Artinya masyarakat diberi ruang (kesempatan) untuk mengemukakan pendapat baik secara lisan maupun tulisan, baik berbentuk orasi, dialog, kritikan, protes dan bahkan demontrasi yang santun untuk menuntut sesuatu yang hak mereka dan sekaligus menunjukkan kelemahan dan ketidak sesuaian kebijakan pemerintah.

Sikap seperti ini seharusnya diberi keleluasaan dan kebebasan, karena ketika mereka berdemonstrasi pada hakikatnya adalah adanya hak mereka yang dizalimi. Secara etika, orang yang dizalimi harus di lindungi dan dibantu dan bukan sebaliknya. Bukankah banyak terlihat ketika pedagang yang tergusur dari tempat mereka mencari nafkah, akhirnya protes dan ternyata bukan protes mereka dipertimbangkan, tetapi justru yang muncul adalah tindakan kekerasan kepada mereka. Seolah-olah mereka sedang berhadapan dengan penguasa, padahal pemerintah hanyalah pembantu rakyat dan bukan penguasa. Kebijakan pemerintah jangan sampai menyakiti hati rakyat, dan pemerintah harus berperan sebagai pengayom yang melindungi rakyat dan bukan menindas dan mengusir rakyat dari tempat tinggal atau tempat mereka mencari nafkah.

Beberapa ilustrasi tersebut diketahui bahwa karakter bangsa yang beradab adalah bangsa yang mau mendengarkan rintihan orang lain, mendengarkan penderitaan sekaligus mengangkat penderitaan mereka dan bukan sebaliknya. ${ }^{24}$

Sikap demokratis merupakan sebuah karakter dari masyarakat madani (beradab), yang mana dalam menjalani kehidupan, warga negara memiliki kebebasan penuh untuk menjalankan aktivitas kesehariannya, termasuk dalam berinteraksi dengan lingkungannya. Demokratis berarti masyarakat dapat berlaku santun dalam berinteraksi dengan sesamanya dengan tidak mempertimbangkan suku, agama, ras dan daerah.

Sikap seperti ini merupakan pengejewantahan dari sikap pengakuan bahwa setiap manusia sama derajatnya tanpa perlu mendapatkan perlakuan diskriminatif. Tetapi dalam kenyataannya sering terlihat bahwa betapa banyak masyarakat yang eksklusif dalam pergaulannya. Kenyataan seperti ini memang banyak dipengaruhi dengan pola hidup feodalisme, yang beranggapan bahwa setiap manusia memiliki strata sosial yang berbeda. Mereka yang dibesarkan dengan pola feodalis, maka sering menjadi feodalis pula. Begitu juga halnya dengan pola hidup yang bersahaja, sikap yang ditimbulkan akan lebih sederhana dan bersahaja, yang dalam istilah sekarang dikenal dengan low profile. 35.

\footnotetext{
${ }^{24}$ Ernest Gellner, Membangun Masyarakat Sipil: Prasyarat Menuju Kebebasan, Cet. I (Bandung: Mizan, 1995),
} 
Jadi masyarakat madani adalah masyarakat yang tidak membedakan sikap dalam pergaulan dengan orang lain tanpa melihat suku, status sosial, pekerjaan dan lain sebagainya. Memang diakui sangat sulit menghilangkan sikap feodalis bagi manusia, termasuk di negara yang demokrasinya sudah cukup maju sekalipun seperti di Amerika, ras kulit hitam sering mendapat diskrimasi dari ras kulit putih.

Sikap toleran merupakan sikap saling menghargai terhadap orang lain, baik menghargai pendapat, keyakinan, pemahaman maupun kebiasaan. Sikap toleransi memang membutuhkan sikap mental yang cukup baik, yakni suatu sikap yang rela menerima perbedaan sebagai sesuatu yang alami dan tidak mau memaksakan pendapatnya untuk disepakati orang lain. Seringkali terlihat banyak kelompok yang memaksakan kehendaknya ketika kelompoknya merasa mayoritas. Karena itulah seharusnya setiap orang mendapat penghargaan terhadap pola pikir yang dimilikinya, sudut pandang dengan cara tidak menggiringnya untuk menyepakati pendapat orang lain. Pluralisme tidak hanya berpandangan bahwa secara realistis masyarakat bersifat heterogen, yakni terdiri dari berbagai etnis, budaya, bahasa, agama, tetapi lebih dari itu mampu menyikapi perbedaan tersebut sebagai sesuatu yang bermakna (rahmat) bagi kehidupan. Bukankah perbedaan yang ada mengisyaratkan agar manusia dapat bersinergi dengan yang lain. Tidak seorangpun atau kelompok yang dapat hidup mandiri dengan tidak membutuhkan orang lain. Si kaya dalam kesehariannya membutuhkan jasa orang miskin untuk membantunya menyetir dan mengerjakan keperluan sehari-hari. Begitu juga parapejabat membutuhkan petani supaya mampu memenuhi kebutuhannya akan beras dan sayur-sayuran.

Sebuah ilustrasi pluralisme dari sisi etnis, di Pekanbaru setiap etnis memiliki okupasi masing-masing. Etnis Minang biasanya bergerak di bidang perekonomian dan jasa kerajinan sangat dibutuhkan etnis lainnya dalam mengembangkan dunia bisnis. Sebaliknya etnis Jawa yang banyak bekerja di sektor perkebunan sangat dibutuhkan semua kelompok masyarakat supaya mampu menikmati sayur-sayuran. Begitu juga halnya dalam memasarkan sayursayuran di pasar didominasi etnis Batak. Maka seharusnya setiap etnis mengucapkan terima kasih kepada setiap etnis yang ada. Bukankah berbagai proyek pembangunan gedunggedung bertingkat bahkan mall banyak dibangun kaum miskin yang merupakan mayoritas pendatang.

Dalam era global kita semua memang sangat membutuhkan, karena setiap kelompok tidak akan mampu memenuhi kebutuhan hidupnya secara mandiri. Setiap etnis membutuhkan etnis lainnya. Maka tidak mengherankan ketika ekonomi dunia bergejolak 
maka berimbas kepada perekonomian bangsa kita. Persoalan kredit macet di bidang perumahan yang terjadi di Amerika telah memberikan efek yang luar biasa bagi perekonomian dunia secara global. Artinya gejolak ekonomi pada sebuah negara akan memberikan pengaruh bagi negara lainnya. ${ }^{25}$

Dengan adanya berbagai kelompok dan etnis dalam sebuah sistem atau menajemen (yang tentu memiliki keahlian yang sesuai di bidang yang dibutuhkan dan moral yang baik), akan muncul saling kontrol antara satu dengan lain, serta bekerja dalam sebuah sistem yang baik. Kondisi seperti inilah yang biasanya mampu menguak segala ketidakberesan, yang biasanya diungkapkan mereka yang tidak mau terlibat dalam korupsi kolektif, yang akhirnya akan muncul sebuah manajemen yang baik dan profesional (good governance).

Karakter berikutnya dari masyarakat madani adalah terwujudnya keadilan sosial pada sebuah bangsa dan masyarakat. Keadilan di sini bermakna bahwa secara sosial masyarakat dalam berbagai strata sosial yang berbeda merasa mendapat keadilan. Keadilan menuntut adanya keseimbangan yang proporsional. Untuk itu sistem pendapatan yang diberlakukan pada masyarakat maupun aparatur pemerintah janganlah terdapat kesenjangan yang besar. Dalam sistem penggajian internasional, bahwa gaji pejabat yang paling tinggi pada sebuah negara adalah 14 kali lipat dari gaji aparat yang paling rendah. Begitu juga dengan gaji yang berlaku pada sektor-sektor kasar seperti buruh tidak berbeda jauh dengan para aparatur negara. Di Australia gaji seorang tukang cuci piring pada sebuah rumah makan tidak jauh berbeda dengan gaji seorang yang bekerja di telekomunikasi. Begitu juga halnya di berbagai negara maju.

Kesenjangan gaji yang tinggi dengan yang rendah merupakan ciri-ciri masyarakat yang feodalistik, yakni masyarakat yang menganggap manusia memiliki status sosial yang berbeda yang karenanya dibedakan hak-haknya secara diskriminatif. UUD 1945 pasal 33 menekankan agar semua kekayaan negara dapat dinikmati oleh semua lapisan masyarakat. Salah satu upaya untuk mewujudkan konstitusi tersebut adalah dengan membuat sebuah struktur penggajian yang lebih adil. Oleh sebab itu barangkali tidak salah untuk meniru negara-negara yang sangat memperhatikan keadilan, yang mana mereka sudah mampu memberikan bantuan biaya hidup bagi para pengangguran. ${ }^{26}$

25 A. Ubaidillah dan Abdul Rozak, Demokrasi, Hak Aqasi Manusia dan Masyarakat Madani, Edisi III (Jakarta: ICCE UIN Jakarta, 2008), 195.

${ }^{26}$ M. Dawam Rahardjo, Masyarakat Madani: Agama, Kelas Menengah, dan Perubahan Sosial (Jakarta: LP3ES, 1999), 56. 
Keadilan sosial juga menuntut adanya pemerataan pebangunan bagi seluruh kawasan di Indonesia. Dengan adanya pemerataan pembangunan diharapkan hasil pembangunan dapat dinikmati rakyat secara keseluruhan. Kemajuan tidak hanya dinikmati oleh orang kota saja, tetapi harus juga dinikmati oleh masyarakat yang berada di kampung. Salah satu dari banyaknya urbanisasi yang terjadi di Indonesia juga disebabkan oleh ketertinggalan desa dibandingkan dengan kota. Barangkali Indonesia sangat pantas meniru Korea Selatan yang memulai pembangunan dari desa, sehingga tidak ada perbedaan yang signifikan antara desa dengan kota. Semua fasilitas dapat diperoleh di desa. Begitu juga halnya berbagai lapangan kerja juga banyak tersedia di desa.

Salah satu dampak positif dari pemerataan pembangunan adalah tidak terjadinya fenomena urbanisasi ke perkotaan, yang mana hal tersebut menjadikan kota menjadi lebih semrawut dan padat, sementara desa semakin ditinggalkan. Bukankah di Indonesia fenomena tersebut sangat terlihat jelas, sehingga menjadikan kehidupan tidak nyaman, sementara banyak desa yang ditinggalkan oleh generasi mudanya karena urbanisasi ke kota, sehingga suatu desa sangat lamban berkembang karena kekurangan pemuda yang dinamis dan kreatif.

Dampak positif lainnya adalah tidak terjadinya kecemburuan antara satu daerah dengan daerah lain yang sudah maju, sekaligus mampu mengurangi kecemburuan antara antara desa dengan kota. Dan sebagaimana diketahui bahwa kecemburuan daerah tidak saja akan mengganggu stabilitas negara, tetapi juga mampu menimbulkan bibit-bibit disintegrasi bangsa. Adanya pemekaran berbagai kabupaten dan propinsi merupakan karena kurang terealiasinya pemerataan pembangunan. ${ }^{27}$

\section{Perilaku Ekonomi yang Diharapakan dari Masyarakat Madani}

Dalam ekonomi islam, perilaku manusia dalam memenuhi kebutuhan sebenarnya berpijak pada landasan-landasan Syariah. Selain itu, juga mempertimbangkan kecenderungan dari fitrah manusia. Dalam ekonomi islam, keduanya berinteraksi secara harmonis sehingga terbentuklah sebuah mekanisme ekonomi yang khas dengan pondasi nilai-nilai ilahiyah.

Ada empat prinsip utama dalam sistem ekonomi islam. Pertama, menjalankan usaha yang halal baik dari produk, manajemen, proses produksi hingga pendistribusian. Kedua, hidup hemat dan tidak bermewah-mewah, bermakna juga bahwa tindakan ekonomi

\footnotetext{
${ }^{27}$ Darmawan Triwibowo, Gerakan Sosial Wahana Civil Siciety bagi Demokratisasi (Jakarta: LP3ES, 2006).
} 
hanyalah sekedar untuk memenuhi kebutuhan bukan memuaskan keinginan. Prinsip ini sejalan dengan Q.S al-A'raf ayat 31-32 dan al-Isra ayat 29. Ketiga, implementasi zakat. Keempat, penghapusan riba atau bunga, gharar dan maisir.

Dalam ekonomi Islam motif dalam aktifitas ekonomi adalah ibadah. Motif ibadah inilah yang kemudian mempengaruhi segala perilaku konsumsi, produksi dan interaksi ekonomi lainnya. Secara spesifik ada tiga motif utama dalam perilaku ekonomi islam yaitu mashlahah, kebutuhan dan kewajiban. ${ }^{28}$ Mashlahah merupakan motif yang dominan diantara ketiga motif yang ada. Mashlahah adalah parameter perilaku yang bernuansa kepentingan bersama. Kemudian motif kebutuhan merupakan sebuah motif dasar, dimana manusia memiliki kebutuhan dasar yang harus dipenuhi. Sedangkan motif kewajiban merupakan representasi entitas utama motif ekonomi yaitu ibadah. Ketiga motif ini saling menguatkan dan menetapkan peran motif ibadah dalam perekonomian. ${ }^{29}$

\section{Simpulan}

Dari penjelasan diatas diharapkan masyarakat madani dapat mengintrepertasikan ekonomi Islam ke dalam kehidupan sehari-hari. Karena sejarah masyarakat madani, juga berasal dari Arab dan dulunya pernah diperjuangkan oleh Nabi Muhammad, kemudian berkembang di Indonesia dan mengalami perkembangan pada masa orde baru. Selain itu, masyarakat madani merupakan masyarakat peradaban yang mengerti akan tatanan hukum di negara, tidak mau terkekang dalam peraturan pemerintah yang mengekang dan memberatkan. Dengan demikian, masyarakat madani tentunya dapat melihat dan memahami fakta dilapangan serta mampu mengembangkan dengan baik dengan adanya sistem ekonomi Islam dalam masyarakat untuk kesejahteraan perekonomian. Ekonomi Islam dapat membentuk suatu aturan dasar di dalam menjelankan perekonomian bagi masyarakat madani dengan merenovasi bentuk-bentuk instrumen sehingga sistem ekonomin Islam senantiasa baru dari masa ke masa.

${ }^{28}$ Muhammad Akram Khan, "The Role of Government in the Economy," The American Journal of Islamic Social Sciences 14, No. 2 (1997): 157.

${ }^{29}$ Nurnasrina, "Ekonomi Islam Sarana dalam Mewujudkan Ekonomi Masyarakat Madani," Hukum Islam 13, No. 1 (2013): 227-229. 


\section{Daftar Pustaka}

Astuti, Ngudi. "Peran Umat Islam dalam Mewujudkan Masyarakat Madani di Indonesia." Jurnal Ilmiah Mimbar Demokrasi 11, No. 2 (2012).

Charis, Irfan. "Pendidikan Islam dalam Masyarakat Madani Indonesia." Mudarrisa: Jurnal Kajian Pendidikan Islam 7, No. 2 (2015).

Gellner Ernest. Membangun Masyarakat Sipil: Prasyarat Menuju Kebebasan, Cet. I Bandung: Mizan, 1995.

Habibullah, Eka Sakti. "Hukum Ekonomi Syariah dalam Tatanan Hukum Nasional." AlMashlabah: Jurnal Hukum Islam dan Pranata Sosial Islam 5, No. 9 (2017).

Jainuri, Achmad. “Agama dan Masyarakat Madani: Rujukan Khusus tentang Sikap Budaya, Agama, dan Politik." Jurnal al-Afkar. Edisi III, Tahun II (2000).

Khalik, Abu Tholib. "Masyarakat Madani dan Sosialisme.” Jurnal Tapis 8, No. 2 (2012).

Khan, Akram. Economic Message of the Qur'an. Kuwait: Islamic Book Publisher, 1996. . "The Role of Government in the Economy." The American Journal of Islamic Social Sciences 14, No. 2 (1997).

Khatibah. "Penelitian Kepustakaan." Jurnal Iqra' 6, No. 1 (2011).

Mas'udi, Wawan. "Masyarakat Madani: Visi Etis Islam tentang Civil Society." Jurnal Ilmu Sosial dan Politik 3, No. 2 (1999). https://doi.org/10.22146/jsp.11137.

Manan, Abdul. Hukum Ekonomi Islam Syariah Perspektif Kewenangan Peradilan Agama. Jakarta: PT Fajar Interpratama Mandiri, 2012.

Mannan, Muhammad Abdul. Teori dan Praktik Ekonomi Islam. Yogyakarta: PT Dana Bhakti Wakaf, 1993.

Mirzaqon T, Abdi. "Studi Kepustakaan Mengenai Landasan Teori Praktik Konseling Expressive Writing." Jurnal BK Unesa 8, No. 1 (2017).

Nurnasrina. "Ekonomi Islam Sarana dalam Mewujudkan Ekonomi Masyarakat Madani." Hukum Islam 13, No. 1 (2013). 
Dwika Mayasari, Sarah Wijayanti Putri, Sistem Ekonomi Islam dengan Aspek Kehidupan....

Nursalim, Eko. "Pendidikan Islam Menuju Masyarakat Madani di Era Globalisasi: Suatu Ikhtiar Menghadapi Tantangan Masyarakat Ekonomi Asean (MEA)." At-Turats: Jurnal Pemikiran Pendidikan Islam 10 No. 1 (2016).

Rahardjo, M. Dawam. Masyarakat Madani: Agama, Kelas Menengah, dan Perubahan Sosial. Jakarta: LP3ES, 1999.

Sulaiman, Thohir Abdul Muhsin. Menanggulangi Krisis Secara Islam. Bandung: Al Ma'rif, 1982.

Sukardi, Imam. "Islam dan Civil Society.” Jurnal Tsaqafah 6, No. 1 (2010).

Triwibowo, Darmawan. Gerakan Sosial Wahana Civil Siciety bagi Demokratisasi. Jakarta: LP3ES, 2006.

Ubaidillah, A, Abdul Rozak. Demokrasi, Hak Azasi Manusia dan Masyarakat Madani, Edisi III. Jakarta: ICCE UIN, 2008.

http://www.majalahgontor.net (Diakses 26 Oktober 2018).

http://ediefendi23.blogspot.com/2016/01/ekonomi-islam-perkembangan-ekonomi.html (Diakses 26 Oktober 2018).

http://www.academia.edu/1511157Gagasan_Civil_Society_Hegelian_dan_Korporatisme_ Negara (Diakses 25 Oktober 2018).. 